\title{
Ecology and Economic Study of Leaf Litter as Organic Fertilizer in Reclamation Land Used on Lime
}

\author{
Supiana Dian Nurtjahyani ${ }^{1 *}$, Dwi Oktafitria ${ }^{2}$, Sriwulann $^{2}$, Nova Maulidina $^{3}$, \\ Imas Cintamulya ${ }^{1}$, Eko Purnomo ${ }^{4}$ \\ ${ }^{1}$ Biology Education Study Program, Faculty of Teacher and Educational Science, PGRI Ronggolawe University \\ ${ }^{2}$ Department of Biology, Faculty of Mathematic and Natural Science, PGRI Ronggolawe University \\ Jl. Manunggal No. 61 Tuban-62381, East Java, Indonesia \\ ${ }^{3}$ Department of Biology, Faculty of Science and Data Analysis, Sepuluh Nopember Institute of Technology \\ Kampus ITS Sukolilo, Surabaya-60111, East Java, Indonesia \\ ${ }^{4}$ PT. Semen Indonesia Tbk Gresik, Semen Indonesia Group \\ Jl. Veteran No.93, Gapurosukolilo, Gresik-61122, East Java, Indonesia \\ *Corresponding E-mail: diananin39@gmail.com
}

\begin{abstract}
The success of reclamation is largely determined by many things including the fertility of the planting media. The fertility of the planting media is related to fertilizer, from the litter found in post-mining land that can be utilized for making organic fertilizer. The purpose of this study is to examine the ecological and economic aspects of leaf litter as organic fertilizer in the reclaimed land of limestone mining. Method: Laboratory experimental research with method Bokhasi Results from this study proved that there are differences in the nutrient content of P, C and N in the reclamation land in 2010,2014 and 2016. Processing leaf litter into organic fertilizer can provide ecological and economic benefits for the company and for the surrounding community.
\end{abstract}

Keywords: ecological aspects; economic aspects; leaf litter; organic fertilizer

\section{INTRODUCTION}

Reclamation and revegetation of former mines is an obligation that must be carried out by companies or holders as stipulated in the Minister of Energy and Mineral Resources decree No. 7 of 2014 [1]. The success of a reclamation is very much determined by many things, including aspects of land management, fertility of the planting media, technical planting and care of plants. Semen Indonesia (Persero) Tbk Gresik has a lot of plants in the treatment period in ex-mining land that needs fertilizer to help plant growth. In addition, in post-mining land, there is a lot of organic waste in the form of dry leaves under the stands of reclamation trees. The organic waste has the potential to be processed and used as organic fertilizer. Therefore it is necessary to do a detailed and in-depth study of the nutrient content in organic waste so that it can be processed into fertilizer.

In the implementation of reclamation a technical soil fertility is required by utilizing the existing potential. One technique that can be used is to utilize organic waste around the mine into fertilizer. The role of fertilizer as the most important component to maintain and improve soil fertility. Fertilizers can also affect plant growth because fertilizers contain nutrients that will determine plant growth. Therefore the problem that arises is whether the existing leaf litter can be used as organic fertilizer and how to make it technical. The purpose of this study is to examine the ecological and economic aspects of leaf litter as organic fertilizer in the reclaimed land of limestone mining.

\section{METHODS}

This research is an experimental study carried out in biology laboratories and in Semen Indonesia. Leaf litter samples were taken from the reclamation soil of the former Indonesia Mining limestone quarry in the Tubar Sumberarum area of East Java he former limestone quarry in 2010, 2014 and 2016, where each sample was taken twice (duplo repetition). Furthermore, the quality of leaf litter was tested based on parameters namely $\mathrm{P}$ Total $\left(\mathrm{P}_{2} \mathrm{O}_{5}\right)$, K Total $\left(\mathrm{K}_{2} \mathrm{O}\right)$, Organic $\mathrm{C}$, and Nitrogen $(\mathrm{N})$.

\section{Organic Fertilizers}

Organic fertilizer in this study was prepared using the bokashi method. At this stage organic fertilizer was made using basic ingredients from leaf litter which was organic material. Leaf litter (40\%) was mixed with husk charcoal (20\%), cow dung / manure (20\%), and fine bran (20\%). Furthermore EM4 biocativator $7.5 \mathrm{ml}$ and molasses $15 \mathrm{ml}$ were prepared then mixed with water. The mixture of solids was watered evenly with a bioactivator solution. The flat mixture was then put into a tarp and covered with 
tarps for \pm 21 days. During the process the temperature was maintained less than $50^{\circ} \mathrm{C}$.

\section{Organic Fertilizer Testing}

Testing the quality of organic fertilizers that have been produced was done by testing the substance content of several nutrient parameters in compost, namely Nitrogen (N) by method Kjedhal, Phosphorus $\left(\mathrm{P}_{2} \mathrm{O}_{5}\right)$ by method Olsen and Bray, Potassium $\left(\mathrm{K}_{2} \mathrm{O}\right)$ by method Spektrofotometri and Carbon (C) by method Walkey and Black in the laboratory.

\section{RESULTS AND DISCUSSION}

Results

The results of leaf litter quality can be seen in Table 1 . TABLE I

RESULTS OF ANALYSIS OF THE COMPOSITION OF NPC IN LEAF LITTER

\begin{tabular}{|c|c|c|c|c|}
\hline \multirow{2}{*}{ Element } & \multicolumn{4}{|c|}{ Reclamation Land Location } \\
\hline & 2010 & & 2014 & 2016 \\
\hline \multirow{2}{*}{$\mathbf{P}(\mathrm{ppm})$} & & 33.57 & 23.86 & 333.39 \\
\hline & & 42.25 & 51.91 & 70.29 \\
\hline Average $\mathrm{P}$ & & 37.91 & 37.89 & 202.14 \\
\hline \multirow[t]{2}{*}{$\mathbf{N}(\%)$} & & 2.82 & 2.24 & 1.83 \\
\hline & & 2.84 & 1.84 & 1.99 \\
\hline Average $\mathrm{N}$ & & 2.83 & 2.04 & 1.91 \\
\hline \multirow{2}{*}{$\mathbf{K}(\%)$} & & 0.0315 & 0.0588 & 0.0506 \\
\hline & & 0.0348 & 0.0881 & 0.0605 \\
\hline average $\mathrm{K}$ & & 0.0332 & 0.0734 & 0.0556 \\
\hline \multirow{2}{*}{$\mathrm{C}(\%)$} & & 26.54 & 16.15 & 5 \\
\hline & & 25.86 & 19.29 & 17.66 \\
\hline Average $\mathrm{C}$ & & 26.2 & 17.72 & 11.33 \\
\hline $\mathrm{C} / \mathrm{N}$ ratio & & 9.26 & 8.69 & 5.93 \\
\hline
\end{tabular}

In table 1 the highest $\mathrm{P}$ element content in the 2016 reclamation land was $333.99 \mathrm{ppm}$, while the highest $\mathrm{N}$ element in the reclamation land in 2010 was 2.84 .

\section{Discussion}

Leaf decomposition can release a number of nutrients and materials that can support the productivity of trees and food webs in mangrove ecosystems. Nutritional value can be defined as a $\mathrm{C} / \mathrm{N}$ ratio (lower ratio means higher nitrogen concentration and higher nutritional quality) [2]. The results of the analysis of the highest value of the $\mathrm{C} / \mathrm{N}$ leaf litter ratio were obtained from the 2016 reclamation land of 19.02 and the lowest value of the 2014 reclamation land with a value of 13.11 (Table 1). This shows that the reclamation land in 2014 has the highest nutrient value of leaf litter than other lands, although the percentage of $\mathrm{N}$ content is lower than the leaf litter on the 2016 reclamation land. This is supported by planting media used for planting teak tree seedlings in the 2014 reclamation land which comes from topsoil. The growing media in the form of topsoil generally has a high nutrient content so that it allows a lot of nutrients to be absorbed by the teak tree and stored on its leaves.

The results of the $\mathrm{C} / \mathrm{N}$ ratio test on the leaves can be used as a basis that leaf litter found in the three reclamation areas can be used as natural fertilizer for the growth of teak trees planted in the area. The low $\mathrm{C} / \mathrm{N}$ ratio value of leaf litter in reclamation land in 2014 means that it has high nutritional quality and will result in a faster decomposition process. Decomposer microorganisms such as Bacillus and Flavobacterium [3][4] will more quickly decompose litter with high nutrient content [2].

Study of the Ecological Benefits of the Utilization of Leaf Litter

Litter has an ecologically important role because it is a source of topsoil, being home to insects and various other microorganisms. Litter also functions as a temporary water storage, improves soil structure, and increases absorption capacity [5][6]. Litter on the forest floor also plays a very important role in maintaining forest productivity and sustainability. The forest floor reduces direct rain kinetic power blows and increases infiltration thereby reducing erosion and an important role in the hydrological cycle. Litter is the main source of nutrients in forest soils and plays a major role in nutrient cycling which is also a store of carbon (carbon stock). In the test results of $\mathrm{C}$ content in teak leaf litter, it can be seen that the litter on reclamation land in 2010 was the highest at $26.20 \%$ (Table 1), then after being processed into organic manure, the $\mathrm{C}$ content increased to $34.89-37.80 \%$. The higher nutrient content of compost, which in turn can also fertilize the soil while providing sufficient nutrients for the growth of teak trees and various types of trees that grow in the reclamation area.

In addition, another nutrient that is very important in soil fertility is the $\mathrm{P}$ element. Based on the results of the test the element $\mathrm{P}$ content in leaf litter of 202.14ppm $(0.02 \%)$ (Table 1$)$ was obtained from reclamation land in 2016 and after compost was made to $0.47-0.42$. This shows that the process of litter decomposition by bokashi method that has been done can increase the $\mathrm{P}$ content in organic fertilizer. High levels of $\mathrm{P}$ in a planting medium can affect the formation of Adenosine Triphosphate (ATP) which play an important role in the process of metabolism and plant growth such as cell division and cell elongation, respiration and photosynthesis [7].

Changes in compounds in the reclamation area in 2010, 2014 and 2016 are due to leaf litter decomposition, and the reclamation conditions in 2010, 2014 and 2016 are now being conducted by analyzing the soil sample reclamation research with high $\mathrm{N}, \mathrm{P}$ and $\mathrm{C}$ elements.

Thus, compost or organic fertilizer derived from leaf litter has the nutrient content needed for plants with 
higher levels than before processing. In addition, compost can also improve soil structure with help from mycorrhizae. Good soil structure is soil that has pores that function in water infiltration (absorption and storage of water in the soil). Fertile soil conditions are also characterized by increasing population and diversity of soil organisms. With fertile soil conditions, it will allow the growth of other types of plants in addition to teak trees which are deliberately planted in the reclamation land. Among the other plants that can live on the reclaimed land are flowering plants that can produce nectar.

The plant will later become attractive or attract insects around the reclamation land to come to the land to eat the nectar. In addition, the increasingly lush condition of the forest and the diversity of plant species will attract the attention of other herbivorous insects to come. Furthermore, the insects will attract the attention of the insectivorous birds to come to the reclamation land. In forests that have formed trees with thick, leafy branches, it will be possible for the birds to build a nest there. In the end the reclaimed land which was not fertile, can recover with a balanced ecosystem condition which is marked by the increasing diversity of plants and animals on the land.

On the other hand, good vegetation conditions, will also help in the absorption of carbon dioxide and convert it into oxygen through photosynthesis. As is well known that carbon dioxide is one of the elements causing global warming and reclaimed land that has become a forest can function as a good store of carbon stock.

\section{Study of the Economic Benefits of Leaf Litter Utilization}

Leaf litter in general has no market value and only certain types of plant dry leaves have a sale value, for example, dried patchouli leaves. But leaf litter in the reclaimed land of the former limestone quarry is only limited to the types of teak and plants that generally grow on karst land. The leaf litter has no economic value in the community and the market so that an effort is needed to increase the economic value of leaf litter, one of which is to use it as organic fertilizer. About $66 \%$ and approximately 7 million agricultural lands in Indonesia are in critical condition. If this condition continues, it will make the damage worse. Most of the soil in Indonesia is poor of nutrients, especially micro nutrients which are needed by plants to increase yields and plant resistance to pests and diseases. One way to restore agricultural soil fertility and increase nutrients in the soil is to use organic fertilizer. Through the Go Organic program, the government is making efforts to increase the production of organic fertilizer as an input for organic farming and also reduce chemical fertilizer subsidies. This effort aims to change the pattern of Indonesian agriculture little by little towards organic farming that is more environmentally friendly and good for health.

The need for organic fertilizer to repair damaged land in Indonesia is very large. This shows that organic fertilizer has a high enough market potential to be developed in Indonesia. The potential market for organic fertilizer can be projected from the results of Puslittanah's research on the status of C-Organic agricultural land in Indonesia, especially in the regions of West Sumatra, South Sumatra, West Java, Central Java, East Java, Kalimantan, NTB, and South Sulawesi. The results showed that the potential for organic fertilizer is very large. For food crops in these areas with an area of around 5.9 million ha, it requires around 3 million tons, while for horticultural crops with an area of about 94 thousand hectares, it requires 190 thousand tons of organic fertilizer. If calculated, the results are obtained that one hectare of paddy farmland requires about 500 kilograms of organic fertilizer and one hectare of holtikutura agricultural land requires about two tons of organic fertilizer. While the absorption of organic fertilizer for the two types of plants has only reached 624 thousand tons.

In Minister of Agriculture decree No. 2/Pert/Hk.060/2/2006, concerning organic fertilizers and soil enhancers, it is stated that organic fertilizers are fertilizers that are mostly or wholly composed of organic material derived from plants and or animals that have gone through an engineering process, can be in the form of solid or liquid used to supply organic material to improve physical, chemical, and biological properties [8]. It's inevitable that organic fertilizer plays a major role major in increasing the fertility of the physical, chemical and biological as well as the efficient use of inorganic fertilizers. The main composition of organic fertilizer when it decomposes and concentration EM4 [9-12].

In Indonesia, organic fertilizer has long been known by farmers. They even only knew organic fertilizer before the Green Revolution struck agriculture in Indonesia. After the Green Revolution, most farmers preferred using artificial fertilizer because it practically used it, the amount was far less than organic fertilizer, the price was relatively cheap because it was subsidized, and easily obtained. Most farmers are already very dependent on artificial fertilizers. This results in a negative impact on the development of agricultural production, especially when there is a scarcity of fertilizers and fertilizer prices rise because fertilizer subsidies are revoked. Growing awareness of the negative impact of the use of artificial fertilizers and other modern agricultural facilities on the environment for a small number of farmers has made them switch from conventional agriculture to organic farming. This type of agriculture relies on nutrient needs through fertilizer organic and other natural inputs. The 
use of organic fertilizer alone on agricultural land cannot have a major influence on increasing crop productivity and food security. Therefore, an integrated nutrient management system that combines the provision of organic fertilizer and inorganic fertilizer in order to increase land productivity and environmental sustainability needs to be encouraged. Only in this way can the sustainability of crop production and environmental sustainability be sustained [13][14].

The agricultural system called LEISA (low external input and sustainable agriculture) uses a combination of organic and inorganic fertilizers that are based on the concept of good agricultural practices so that land degradation can be reduced in order to preserve the environment. The use of organic fertilizer to increase land productivity and agricultural production needs to be promoted and promoted. Agricultural development programs that integrate livestock and crops as compost need to be intensified. One indicator of the success of land rehabilitation is increasing the number of types of land rehabilitation [13-15].

Land that is too often given inorganic fertilizer, will eventually become hard. This situation will cause several difficulties, including the soil becomes difficult to cultivate and plant growth becomes disturbed. Soil fertility and soil will be maintained if we always add organic material, which is organic fertilizer. The use of organic fertilizer is highly recommended because it can improve soil productivity, both physically, chemically, and biologically. Physically, organic fertilizer can loosen the soil, improve aeration and drainage, increase binding between particles and water binding capacity so that it can prevent erosion and landslides, reduce the loss of dissolved nitrogen, and improve tillage. Therefore the use of organic fertilizer is very necessary. With the use of leaf litter as organic fertilizer in the reclaimed land of the former limestone quarry, it can be possible to reduce the expenditure costs for the need to purchase inorganic fertilizers which are increasing with study, it was found that with the analysis of the organic bokashi litter charcoal litter charcoal that benefits farmers, the results of the analysis can be seen in Table II.

The profit for the sale of organic fertilizer is IDR. 850,000 per $1.000 \mathrm{~kg}$ of fertilizer production. This advantage can be increased by several alternatives, namely: a) do not use husk charcoal sold in the market but wood charcoal obtained from the limestone mine reclamation land; b) do not use manure sold in the market but use cow dung directly obtained from farm animals of farmers; c) Using sawdust or sawdust which has a price of half the price of bran on the market; d) use of organic wastewater for watering fertilizer to increase the population of decomposer microorganisms so that the decomposition process takes place more quickly; e) Addition of wet organic waste originating from food scraps to speed up the decomposition process. Shows the use of organic fertilizer to increase the population of soil bacteria from $10^{2}$ to $10^{7}[16]$.

TABLE II

ANALYSIS REQUIREMENT

\begin{tabular}{lcrr}
\hline \hline Requirement & Unit & $\begin{array}{c}\text { Price } \\
\text { (IDR) }\end{array}$ & \multicolumn{1}{c}{$\begin{array}{c}\text { Total } \\
\text { (IDR) }\end{array}$} \\
\hline Chaff charcoal & $200 \mathrm{~kg}$ & 5,000 & $1,000,000$ \\
Bran & $200 \mathrm{~kg}$ & 5,000 & $1,000,000$ \\
Cow dung & $200 \mathrm{~kg}$ & 5,000 & $1,000,000$ \\
Molasses & $1 \mathrm{~kg}$ & 20,000 & 20,000 \\
EM4 & $1.5 \mathrm{liter}$ & 20,000 & 30,000 \\
Miscellaneous expense & & & 100,000 \\
\hline Cost of Production & & & $\mathbf{3 , 1 5 0 , 0 0 0}$ \\
\hline Organic fertilizer sales & $500 \mathrm{~kg}$ & 8,000 & $4,000,000$ \\
\hline Total Income & & & $\mathbf{4 , 0 0 0 , 0 0 0}$ \\
\hline Net Profit & & $\mathbf{8 5 0 , 0 0 0}$ \\
\hline
\end{tabular}

\section{CONCLUSION}

Processing leaf litter into organic fertilizer can provide ecological and economic benefits for the company and for the surrounding community. Ecologically, the processing of leaf litter can help the process of restoring the function of karst areas that have an important role in the ecosystem, such as providing clean water, maintaining biodiversity and controlling climate change. Whereas economically, it is beneficial in reducing the cost of purchasing fertilizer, maintaining green open land, and reducing the level of risk of forest fires in the dry season due to the accumulation of leaf litter on the reclaimed land of the former limestone quarry.

\section{ACKNOWLEDGMENT}

Would like to thank PT Semen Indonesia (Persero) Tbk of research funding facilities, Biology Laboratory Staff of ITS Surabaya and Biology Laboratory Staff of PGRI Ronggolawe University Tuban for their cooperation in processing and analyzing samples.

\section{REFERENCES}

[1] Minister of Regulation Energy and Mineral Resources Republic Indonesia. 2014. Decrre No. 7 of 2014 about Implementations of Reclamation and Post Mine in Mineral and Coal Mining Business Activities. Access on 23 March 2019. Available at: https://jdih.esdm.go.id/index.php/web/result/828/deta il. 
[2] Asthon EC, PJ Hogarth, R Ormond. 1999. Breakdown of mangrove leaf litter in a managed mangrove forest in Peninsular Malaysia. Hydrobiologia. 413: 77-88.

[3] Astutik RP, ND Kuswytasari, M Shovitri. 2012. Test of cellulase and xylanase activities of soil mold isolates Wonorejo Surabaya. ITS Library. http://digilib.its.ac.id/ITS-Undergraduate3100011045219/17619.

[4] Alami NH, WP Septarina, T Pratiwi, ND Kuswytasari, E Zulaika, M Shovitri. 2019. Extracellular Alkaline Phosphatase from Mangrove Soil Yeast. Akta Kimia Indonesia. 4(1): 15-31.

[5] Rindyastuti R, AS Darmayanti. 2010. Komposisi Kimia dan Estimasi Proses Dekomposisi Seresah 3 Spesies Familia Fabaceae di Kebun Raya Purwodadi. UPT Balai Konservasi Tumbuhan Kebun Raya Purwodadi. Prosiding Seminar Nasional Biologi 2010. Yogyakarta. Universitas gadjah Mada.

[6] Windusari Y, NA Sari, I Yustian, H Zulkifli. 2012. (Estimation of carbon biomass from the understorey and litter vegetation at tailings deposition area of PT Freeport Indonesia Biospecies. 5(1) 22-28.

[7] Frey S, A Leskovar, J Reinstein, J Buchner. 2007. The ATPase cycle of the endoplasmic chaperone Grp94. J. of Biological Chemistry. 282(49): 3561235620 .

[8] Minister of Agriculture. 2019. Decrre No. 02/Pert/Hk.060/2/2006 about Organic Fertilizer and Soil Plants. Access 23 March 2019, Aviable on perundangan.pertanian.go.id $>$ admin $>$ p_mentan $>$ Per mentan-02-06.

[9] Simanungkalit RDM. 2006. Prospek Pupuk organik dan pupuk hayati di Indonesia. In: Pupuk Organik dan Pupuk Hayati, Ed.: DA Suriadikarta, R Saraswati, D Setyorini, W Hartatik. Jawa Barat. Balai Besar Penelitian dan Pengembangan Sumberdaya Lahan Pertanian. Bogor. Hal. 265-271.

[10] Hartatik W, H Usnain, LR Widowati .2015. Peranan pupuk organik dalam peningkatan produktivitas anah dan anaman. J. Sumberdaya Lahan. 9(2):107-120.

[11] Khan MAI, K Ueno, S Horimoto, F Komai, K Tanaka, Y Ono. 2009. Physicochemical, including spectroscopic, and biological analyses during composting of green tea waste and rice bran. Biol Fertil Soils. 45:305-313.

[12] Kurniawan D, S Kumalaningsih, NMS Sunyoto. 2011. The effect of effective microorganism 4 (EM4) volumes addition $1 \%$ and fermentation time on quality of bokashi fertilizer made from rabbit feces and jackfruit waste. Jurnal Industria. 2(1): 57-66.

[13] Anggana F A, AS Cahyono, YC Lastiantoro. 2019. Keanekaragaman Hayati di Lahan Rehabilitasi Taman Nasional Meru Betiri Dan Implikasi Kebijakannya: Kasus DesaWonoasri. Jurnal Ilmu Lingkungan. 17(2): 283-290.

[14] Asngad A, Supardi. 2005. Development model for making organic fertilizer with inolucation (a case study on rubbish at tpa mojosongo, surakarta). Jurnal Penelitian Sains \& Teknologi, 6(20):101-111.

[15] National Standardization Agency. 2004. SNI 197030 2004. Specifications for Compost from Domestic Organic Waste. Access on 23 March 2019, Aviable at: https:www.bsn.go.id.

[16] Wahyuni S, Rianto S, Muanisah U, Setyanto P. 2016. The Use of Organic Fertilizers to Population Bacteria and Dry Land Paddy Production. Proceding Biology Education Conference. 13(1): 752-756. 